\title{
Dangerous Chemical Agents: General and Odonto- Stomatological Aspects with Importance in Forensic Toxicology
}

\author{
TATIANA IOV ${ }^{1}$, MIHNEA COSTESCU2*, MADALINA DIAC ${ }^{3 *}$, DANIEL TABIAN3*, SOFIA MIHAELA DAVID³, ANTON KNIELING ${ }^{3}$, \\ SIMONA IRINA DAMIAN ${ }^{3}$ \\ ${ }^{1}$ Institute of Legal Medicine of Iasi, 4 Buna Vestire Str., 700455, Iasi, Romania \\ ${ }^{2}$ Carol Davila University of Medicine and Pharmacy, 8 Eroii Sanitari Blvd., 050474, Bucharest, Romania \\ ${ }^{3}$ Grigore T.Popa University of Medicine and Pharmacy, 16 Universitatii Str., 700115, Iasi, Romania
}

\begin{abstract}
In the heavy and light industry, the food and pharmaceutical industry, there are chemicals that contain metals with high toxic potential. Toxicity of metals is due to the harmful effect in certain forms and doses. Some metals become toxic when they form soluble compounds or in a certain chemical structure at certain doses (eg lead, mercury and candium). Not only heavy metals are toxic metals, there are also light metals that can become toxic, some of which are essential elements (iron, selenium, copper, chromium, zinc) and metals used therapeutically in medicine (aluminum, bismuth, gold, gallium, lithium and silver) may have negative effects when administered in large quantities or the elimination from the human body is deficient. Metal poisoning occurs through nutrition, medication, environmental factors. Most professional pollutants with intraoral manifestations appear in the heavy industry. The oral cavity is an entry gate for various toxic pathogens, so intoxications can be detected early due to the manifestations inside the mouth.
\end{abstract}

Keywords: chemical agents, intoxication, toxic effects, dento-periodontal lesions

Intoxication with various substances has often generated different medical problems that sometimes have complications associated with death. Forensics report that alcohol, drugs or various metals have had such effects [1-4]. The effects are stronger as the age or the conflicting contexts add more vulnerability, or where nature creates imbalances in the local chemical panel [5-8]

Lead enters the body by ingesting foods contaminated with lead (plants growing in lead-rich soil or fish from contaminated waters $[9,10])$, by the use of lead-based paints or in the urban environment, where lead-based petrol is used in motor vehicles. Studies on mice have highlighted the effect of this substance in cardiological disorders [11, 12], butalso allowed the establishment of toxicity mobility patterns in various areas [13-16].

Lead is found in paints, automotive components, hair dyes, candy, PVC products, gasoline, potable water (through pipe contact), soils using pesticides, firearms, explosives. Ocean fish and refined chocolate are sources of lead and mercury.

Lead is most commonly absorbed through the respiratory or gastrointestinal route [17, 18], either in the occupational context or through scientifically or naturally based medication [18, 19]. It is initially distributed to soft tissues (liver, kidney), then attached to bones, teeth or hair. Lead is a chemical like calcium metal, the body assimilating it as calcium. The transport pathway is plasma and the soft tissue membranes are distributed to the teeth and bones. Blood lead elimination time is 30 days but from bones it is eliminated in 25 years. In the body, lead alters brain activity - it inhibits intracellular messengers [20].

Lead in blood is measured in micrograms per deciliter, a level of e" $5 \mathrm{mcg} / \mathrm{dl}$ indicating an acute lead intoxication.

Mercury is a metal in Block D of metals in the Periodic System being one of the 6 liquid elements at room temperature (mercury, gallium, cesium, francium, rubidium-metal- and bromine-non metal) [21]. Mercury is found in: polluted diesel fuel, cherosene, hot oil, soil, water, coal, oil refineries, and crematoriums. It is widely used in industry for the manufacture of various appliances (thermometers, barometers, pressure gauges). In dentistry it is used in the form of amalgam. Mercury is part of thiomersal with a role in preserving vaccines. It is also found in drops for the eyes, nose or ears and in various antiseptic, diuretic or laxative preparations. Mercury is found in economic bulbs, electrical outlets, thermostats, ocean water where it is converted by bacteria into toxic mercury that accumulates. Mercury is not toxic in its insoluble form (as sulphide), but only in its soluble form as chlorides or monomethylmercury $\left(\mathrm{CH}_{3} \mathrm{Hg}+\right)$. Due to the cationic form, it can react with other anions, including the -SH group in the structure of cysteine, glutathione, homocysteine, metallothionins and albumin with which they form covalent bonds. In general, intoxication occurs after absorption through the skin or after vapor inhalation. The organic compounds have a high toxicity (methylmercury and dimethylmercury) that can cause acute or chronic poisoning. Mercury affects the central nervous system, endocrine system, kidneys, gums and teeth. Prolonged exposure to mercury vapors causes damage to the nervous system and eventually death [22].

Mercury can be dosed in blood, urine, hair, nails, and cerebrospinal fluid. In acute poisoning, blood levels are useful, and in chronic poisoning when measuring mercury concentration in hair, a value of $>1.2 \mathrm{mcg} / \mathrm{g}$ supports chronic intoxication. Methylmercury concentrates in erythrocytes. Paresthesias occur at a level $>20 \mathrm{mcg} / \mathrm{dL}$ of mercury in the blood. The value of $>50 \mathrm{mcg} / \mathrm{dL}$ in chronic exposure increases the frequency of tremors. The presence of mercury in the toenails indicates long-term exposure to mercury, the average values of $0.45 \mathrm{mcg} / \mathrm{g}$ should be correlated with the consumption of ocean fish and seafood.

Arsenic is a heavy metal which in nature exists under three alpha forms (white), beta (black), gamma (gray). Arsenic is found in: pesticides, herbicides, fungicides, glass,

*email :mihneacostescu@yahoo.com; madalina_dc89@yahoo.com; tabiandaniel@yahoo.com 
ceramics, semi-conductors, paints, soaps, medicines, fruits, contaminated drinking water, tobacco, wiskey. Metallic arsenic enters into the composition of certain organic or inorganic compounds, the inorganic ones exhibiting higher toxicity [23-26]. Elemental arsenic is the least toxic. Trivalent arsenic is very well absorbed through the skin and is 60 times more toxic compared to pentavalent that is well absorbed in the intestine. Arsenic gas is very toxic. Arsenic toxicity is due to its effect on cellular enzymes that cause oxidative metabolism and repair the DNA. Mitochondria accumulates arsenic. Arsenic inhibits succinyl dehydrogenase and decouples oxidative phosphorylation. Arsenic interferes with mitochondrial energy function in two ways: competition with phosphate in the case of oxidative phosphorylation and inhibition of NAD reduction. These mechanisms lead to a decrease in ATP synthesis and increase the synthesis of peroxidases with reactive oxygen species and oxidative stress. People most sensitive to poisoning are those with diets that are deficient in vitamin $B$ and antioxidants. Arsenic intoxication is a disease caused by ingestion followed by absorption or inhalation of dangerous levels of arsenic, is also possible in case of acute intoxication with Paracetamol.

Plasma arsenic testing is useful, but rarely available; the arsenic concentration should not exceed $50 \mathrm{mcg} / \mathrm{L}$.

The diagnosis of arsenic intoxication is established after determining the level of arsenic in the blood and urine. The actual concentration of arsenic in the body can be determined by blood arsenic levels only within the first $24 \mathrm{~h}$ of exposure. Organic arsenic compounds detected in urine usually come from food (fish, seafood) if they were consumed 12 days before harvesting, and the lab should differentiate non-toxic arsenic from inorganic arsenic (toxic). In hair follicles, arsenic can be detected $30 \mathrm{~h}$ after exposure. In chronic poisoning, the urine arsenic level and the arsenic concentration in pile follicles are also examined, as well as the level of arsenic in drinking water, since the correlation between increased arsenic concentration in water and patient symptomatology is useful for the diagnosis of chronic intoxication. Normal arsenic level: Blood <50 micrograms / liter, urine $<50$ micrograms / 24h, normal arsenic concentration in urine $<30$ micrograms / L.

Aluminum is the most abundant metal in the Earth's crust. Aluminum and aluminum salts are used in the agrofood industry, construction, transport, packaging, pharmaceuticals, surgery, cosmetics, treatment of potable water. It can be found in almost all foods (naturally present in most fruit and vegetables, but is added to most food products even in baby milk and is used as an additive, as a preservative, coloring agent, adhesion agent, anti-caking agent), drinking water (add aluminum sulphate to make it transparent), anti-inflammatory pain medications, buffered aspirin (may contain 10-20 mg aluminum / tablet), antacids (contain approximately $300-600 \mathrm{mg}$ aluminum hydroxide - 104-208 mg aluminum / tablet / capsule / $5 \mathrm{~mL}$ per liquid dose), vaccines (containing aluminum compound as adjuvant not more than $0.85 \mathrm{mg}$ I dose - most vaccines contain aluminum hydroxide to increase vaccine efficacy), cosmetics (to facilitate the absorption of creams in the skin, as a hardener for the nail polish, to give the white color), shower products, deodorant ( $90 \%$ of deodorants contain aluminum salts). It is used in the manufacture of kitchen utensils, foil wrapping food, beer and water cans. Aluminum phosphide is commonly used for cereal processing. Aluminum fluoride used to treat household water is the most dangerous compound. Its absorption is through the lungs, skin, passes through biological membranes and can accumulate in the body after the abuse of aluminum-based antacids. It is an additive that is put in the baking powder, is found in the fluoride toothpaste in foods packed in aluminum and those from greenhouses [27-29].

In the body, the aluminum after absorption is distributed in almost all organs, the accumulation being in the bone system, transforming into $\mathrm{Al} 3$ + affecting the metabolism of calcium, iron, phosphorus, fluoride, and the maximum admitted dose is $1.0 \mathrm{mg} / \mathrm{kg} /$ day. Aluminum can be dosed in blood, faeces, urine. Urine analysis is the safest way to detect excess aluminum because it is eliminated through the urine. To determine the level of aluminum in the body, hair is analyzed [30, 31].

Copper, even if it is a metal, becomes an indispensable element of life, found in all tissues of the body, most of which is found in the liver; smaller amounts are found in the brain, heart, kidney and muscle. Copper helps the body use iron in the blood, reducing the effects of free radicals on tissues. Consuming copper can also prevent certain illnesses or deficiencies such as allergies, baldness, AIDS, leukemia, osteoporosis and gastric ulcer. Together with iron, copper helps synthesize red blood cells [32].

The daily requirement for an adult is $2.5 \mathrm{mg}$ and for children the daily requirement is based on body weight: $0.05 \mathrm{mg} \mathrm{Cu} / 1$ kilo bodyweight. Copper-rich food sources are: meat (liver, kidney), crustaceans, mollusks, green vegetables (leaves) and dried vegetables, fruits (nuts, grapes and almonds). Copper from food consumed is absorbed in the stomach and small intestine in a ratio of only $30 \%$ and is stored in the liver, kidney, heart and brain. The bones and muscles have low levels of copper, butbeing in a large proportion in the body, about $50 \%$ of the total amount of copper is distributed in the bones and muscles.

In spite of these beneficial effects, the poor dissipation of copper in the body can lead to three rare diseases:

- Wilson's disease, when the body is unable to regulate copper absorption and so copper accumulates in the liver;

- Menkes disease, when the body cannot make copper reserves, resulting in its lack;

- copper toxicosis (it is a disease of unknown origin and very rare, especially in children), the copper accumulates in the liver.

People working in mines or in processing copper ores can encounter intoxication manifested through abdominal cramps, nausea, diarrhea, vomiting, and anemia.

Combinations of Cu (II) have local irritantaction, toxicity in myocardial striated muscles causing paralysis and cardiac arrest. Also, some combinations of Cu (II) produce hemolytic anemia, toxicity manifested in the liver and kidneys [33, 34].

$\mathrm{Cu}^{2+}$ ions form complex combinations with albumin or lipid in the liver, kidney, pancreas, nervous system, bone.

Copper dosing: in acute plasma poisoning (venous blood is harvested), elevated serum copper $(\uparrow, \uparrow \uparrow)$, normal ceruloplasmin, normal hepatic copper level, increased urinary copper $(\uparrow)$, in chronic intoxication in the urine from the latest $24 h$, or in a sample of spontaneous urine, elevated serum copper $(\uparrow)$, increased ceruloplasmin ( $\uparrow$ ), increased liver copper level $(\uparrow, \uparrow \uparrow)$, increased urinary copper $(\uparrow)$ [35].

Bismuth is a metal used in the manufacture of lowmelting temperature alloys and in the form of combinations (basic bismuth salts - bismuth substrate, bismuth carbonate) is used in medicine (as insoluble salts with a gastroprotective and antiseptic effect), in cosmetics (in the manufacture of lipsticks, nail polish and eye shadow, which confers a pearl color) and in the glass industry and 
is also found freely in nature or in the form of mineral (bismuthine and bismuth oxide). Bismuth alloys are used for the manufacture of metallic materials, special welds (welding of cast iron parts), plugs for automatic spraying systems, electric fuses and many fire protection systems. From an environmental point of view, bismuth is neither toxic nor harmful to the environment. From an industrial point of view, bismuth is considered one of the least toxic heavy metals.

Although the degree of destruction is poor, bismuth and its salts may cause kidney problems, and high doses may be fatal. Bismuth poisoning can sometimes be fatal by injecting large doses into closed body cavities (used as a medicine), and by long-term application on burns (in the form of bismuth-soluble compounds). In bismuth poisoning, the symptoms are gastric ulceration, the presence of albumin and other protein substances in the urine, diarrhea, skin reactions and sometimes exodermatitis, whereas in chronic poisoning one can experience bismuth encephalopathy characterized by confusion, myoclonus, and dysarthria.

Cadmium is a highly toxic heavy metal, dangerous even when we are exposed to very low doses. It is mainly used in the electro-galvanization process and in atomic-nuclear reactors. It is found in food, water and air. Normal dietary intake of cadmium varies between 2 and $200 \mathrm{ig} /$ day [36, 37].

The most important sources of cadmium are foods grown in soils rich in this heavy metal and cigarette smoke, about two thirds of the daily intake of cadmium comes from vegetable sources and one third from animal sources (mostly grains $(26.9 \%)$, vegetables $(16 \%)$ and starchcontaining roots (13.2\%) potatoes representing $13.2 \%$, bread $11.7 \%$, chocolate $4.3 \%$, lettuce, spinach and other leafy vegetables $3.9 \%$, mollusks $3.2 \%$, oceanic fish). For people with low iron intake, cadmium absorption is 3.4 times higher than normal (adequate iron intake reduces the absorption of this heavy metal). An important source of cadmium is tobacco, a plant that has the ability to accumulate cadmium regardless of the concentration present in the soil. Cadmium content in tobacco varies greatly, but the average concentration is $1-2 \mu \mathrm{g} / \mathrm{g}$ dry substance (0.5-1 $\mu \mathrm{g} /$ cigarette). Cadmium oxide produced during tobacco smoke is very well absorbed by the body, $10 \%$ of the inhaled amount is stored in the lungs, and 30 $40 \%$ goes into the bloodstream; smokers have a blood cadmium concentration that is 4-5 times higher than nonsmokers and in the kidneys 2-3 times higher than these.

The acute toxic effects of cadmium depend on the route of exposure. Once entered into the body, it is very easily stored by it, therefore it accumulates throughout life. It accumulates in the organs because there is no active mechanism to remove it and only $0.001 \%$ of the amount of cadmium in the body is eliminated daily. Cadmium is very toxic for the kidneys (the main organ in which it accumulates), causing kidney damage (tubular and / or glomerular dysfunction with proteinuria, alteration of urine concentration capacity and decreased clearance to inulin); the amount accumulated in the kidneys is over 18 times higher than that accumulated in the liver. Inhalation of large amounts of cadmium particles produces in the first stage fever, headache, nausea, vomiting, nasopharyngeal irritation, coughing, shortness of breath, followed by installation of a chemical pneumonia and possibly a fatal acute pulmonary edema. Chronic exposure to cadmium particles in breathing air can cause pulmonary emphysema. Cadmium can cause bone demineralization (disturbance of bone metabolism with osteomalacia, osteoporosis and increased risk of spontaneous fractures), and when absorbed directly from the atmosphere, the risk of lung cancer increases considerably. Cadmium nephrotoxicity can be manifested by proteinuria, calcium, aminoaciduria, glycosuria, or destruction of renal tubular cells and glomerular fibrosis. It remains in the kidneys throughout life with a half-life of 30 years. Thus, even if no new amounts of cadmium are ingested, there may be symptoms of intoxication. Exposure to small amounts of cadmium for prolonged periods can cause renal blockage, early onset of kidney complications associated with diabetes, osteoporosis, fluctuating blood pressure and a high risk of cancer. In the case of pregnancy, a high consumption of cadmium-containing foods or smoking results in a higher rate of premature birth, and in the case of breastfeeding they have caused obesity and early adolescence in puberty. In terms of lung cancer, cadmium is considered a substance that favors its appearance, and given that cigarettes are an important source of cadmium, they are also a determining factor in the development of lung cancer. Cadmium is also associated with an increased risk of breast, prostate and colon cancer. It may also harm the testicles.

Dosage of cadmium in the blood: diagnosis of acute or chronic exposure to cadmium, cadmium in urine: monitoring of chronic intoxication and estimation of cadmium loading. Reference values: cadmium in the blood: non-smokers: 0.3-1.2 $\mathrm{gg} / \mathrm{L}$, smokers: 0.6-3.9 $\mu \mathrm{g} / \mathrm{L}$; Occupational exposure: $\mathrm{SBL}$ (safe biological limit) $=5 \mu \mathrm{g}$ / $\mathrm{L}$; cadmium in urine: non-smokers $<2 \mu \mathrm{g} / \mathrm{g}$ creatinine, $<3 \mu \mathrm{g} / 24 \mathrm{~h}, \mathrm{LBT}=$ tolerated bioavailability $=5 \mu \mathrm{g} / \mathrm{g}$ creatinine; conversion factor: $\mu \mathrm{g} / \mathrm{L} \times 8.897=\mathrm{nmol} / \mathrm{L}$; $\mathrm{nmol} / \mathrm{L} \times 0.112=\mu \mathrm{g} / \mathrm{L}$.

Vanadium is mainly used as Fe-V alloy- ferrovanadium in the production of alloyed steels - because it improves mechanical properties, increases hardness, shock resistance and resistance to corrosion. It is also used in nuclear reactors with fast neutrons. Vanadium carbide is also used in alloyed steels for the manufacture of chemical apparatus. Vanadium pentoxide is a good catalyst in oxidation reactions.

Vanadium is an active agent in stimulating body metabolism, being particularly useful for bone growth, tooth hardening, adequate thyroid function, fertility and hormone production. The daily dose required for the human body is 10-100 micrograms per day. Natural sources of vanadium are found in seafood, radishes, bread, whole grain cereals, vegetables, nuts, oils, strawberries, black pepper, mollusks, mushrooms, seeds, dill, parsley, soy, wheat, olive oil, olives, gelatine, rice, chicken, duck meat, fish, peanutbutter, eggs, beer, wine. Vanadium is also a mineral that is found in the air. Most vanadium is excreted through the faeces, only 5 $10 \%$ being effectively absorbed.

If vanadium is not used as present in the natural compounds, it can be toxic, because inorganic salts of vanadium are not soluble enough, it is difficult to absorb having a high toxicity, the effects of this fact can be: vomiting, bloating, abdominal cramps, anemia, decreased white blood cell count, growth deficit, liver and nervous system damage, kidney failure, diarrhea and loss of appetite and even death. The toxodynamic mechanism of the pentavalent vanadium is determined by the fact that it is an inhibitor of the sodium / potassium enzyme membrane. Also, vanadium that is administered in relatively high intraperitoneal doses in mice resulted in decreased glutathione, NADPH and NADH. In cytochrome P450, vanadium inhibits the dealkylation of some drugs [38]. 


\section{Odonto-dental aspects}

Acute poisoning with toxic metals in the buco-maxillofacial area can range from simple loco-regional inflammatory reactions to pronounced necrotic and haemorrhagic lesions [34-37].

In acute poisoning, we observe changes in both the vestibular mucosa and the teeth. Atthe level of the vestibular mucosa, we recognize the following lesions:

- abundant sialorrhea (excessive secretion of saliva) , which is caused by the salts of antimony;

- discoloration of vestibular mucosa: yellowish vestibular mucosal staining by contact with rivanol, picric acid, etc., the brown color of the vestibular mucosa but also of the teeth may appear in nicotine intoxications, iron salts, iodine vapors; bluish or greenish coloration in copper poisoning or medicines stained with methylene blue;

- erosions (exulcerations) of the vestibular mucosa that are caused by zinc chloride in concentrated solution and dilute mercury solutions;

- Acute toxic stomatitis recognized by redness and swelling of the lining of the mouth, gums or tongue, soft palate edema extending in the larynx, sialorrhoea, with acute onset on contact with some substances (bromide, iodine, dilute solutions of acids or bases) or medication, lack of fever and regional adenopathy, the presence of other signs of acute or subacute poisoning. Early signs of stomatitis, as a clinical expression of occupational poisons, include elemental lesions such as papules, vesicles or pustules, as well as continuity solutions such as erosion, cracking. $[9,10]$;

- phlyctenular stomatitis can be caused by toxic substances of vegetable origin (eg mustard extract) or animal (bee venom) and some medicinal substances (antibiotics, novocaine)

- necrosis of the vestibular mucosa, caused by the action of acids (hydrochloric, hydrofluoric, sulfuric, acetic, thinners), chlorine or concentrated alcohol solutions, benzols, phenols, sodium chloride, formalin, hydrogen peroxide, mineral salts;

- hemorrhagic necrosis and ulceration occur in poisoning with caustic substances in gaseous or vaporous state (chlorine, ammonia, hydrochloric acid, phosphorus);

- esters: in the case of concentrated sulfuric acid are blackish, in the case of hydrochloric acid they are brown, in the case of silver nitrate they are brownish-black, in the case of nitric acid they are yellowish, in the case of copper sulphate they are green, in the case of sublimation they are grayish-green.

In acute poisoning with nitric acid or hydrochloric acid, when we examine the teeth we recognize erosive tooth lesions, necrotic cavities, acute pulpitis, dental necrosis accompanied by gingival necrosis or toxic parodontitis.

In chronic poisoning, especially pre-existent cavity lesions, toxins that enter the root canal cause necrosis of jelly-colored jaws (in contact with phosphorus, arsenic, mercury, radioactive substances).

In professional chronic poisoning one can identify:

In case of lead poisoning (saturnism): $85 \%$ of the pigmentation of the blue linear / 1-2 mm thick blackish gums edge (one of the first diagnostic signs), following the dental arch, the interruption in the space with teeth (Burton's halo). Pigmentation predominates in the anterior region of the lower gum and traumatic areas (tartar, caries, prostheses). It can be associated with salivation, aloin tongue, fetid halitosis, gingivitis with dark lining, saturnine erythematous stomatitis, deposits of lead sulphide grains that lead to tattoo-looking stains on the lining, painful swelling of the salivary glands, in which case we should seek other manifestations of poisoning (digestive, hematological, renal, neurological) with dosing serum and urinary lead, saturnine periodontitis and early tooth loss.

Oral lesions in mercury poisoning (hydration) are: dry mouth or hypersalivation. An important sign is the tremor of the tongue and lips, and later of the extremities, which exacerbates in the course of voluntary movements, ulceronecrotic stomatitis, fetid halitosis, submandibular adenopathy, catarrh congestive stomatitis, mercurial halo, mercurial tooth, chronic hyperplasic gingivitis that aggravates and complicates with mercury parodontopathy, with pharyngitis and discrete edema of the tongue. A grey gum halo can appear afterwards, lighter and thicker than Burton's halo. Teeth get gray (mercurial teeth), start to shake and are spontaneously expelled.

In copper poisoning: gum halo, enamel lesions, brown enamel color, gingivitis, greenish tinge of gums, chronic marginal periodontitis, metallic-sweet taste.

In the case of arsenic intoxication (arsenicosis) alveolar necrosis occurs.

Bismuth causes a blackish-gray coloration of the gum, lining of the mouth and tongue, gum bismuth halo, tattoo plates, bismuth stomatitis.

Chronic silver intoxication (argirism) due to the excessive use of local treatments (silver nitrate) translates into a gray-blue tinge of the gum or mucous membrane.

The cadmium may give a yellowish lining around the teeth.

Vanadium - greyish-black color of the tongue and black macula at the level of the upper lip.

Prolonged exposure to textile powders can cause bisinose. The textile powder contains plant dust with organic and mineral impurities and is contaminated with germs and fungi. Dust from mills plays an important role in oral mucosa. Intraoral clinical examination in the case of professional textile poisoning shows xerostomia, increased viscosity and saliva acidity with the frequent occurrence of carious lesions and chronic inflammation of the oral mucosa [39-42].

\section{Conclusions}

Due to the exposure to the effects of various noxes, different dangerous toxic agents enter the body through the oral cavity, either by ingestion of liquids or food that is chemically affected.

Some metal intoxication may be recognized after lesions in the buccal-maxillo-facial area, lesions that may occur as a result of the local action of toxic substances or as an expression of their specific action.

Collaboration between the dentistand the forensic doctor plays an important role in the early detection of noxes with intraoral clinical expression and in establishing a diagnosis that reflects their oral pathology.

Considering that the periodontal tissues show the signs of the diseases caused by the professional noxes, with clinical implications on the dento-maxillary functioning, the collaboration between the dentist, the forensic physician and the occupational medicine physician has an important role in the early detection of the professional injuries.

Since it is difficult to measure heavy metal consumption, the most prudent is to try to limit exposure, especially in vulnerable categories, by carefully studying the labels of consumer products.

\section{References}

1.RADU, C.C., BULGARU-ILIESCU, D., Claims of uniqueness in forensic medicine, Romanian J ournal of Legal Medicine, 2016, vol. 24(4): 343345 
2.MACOVEI, L.A., CRISTESCU, V., DEBITA, M., DINU, C.A., Oral Manifestations of Osteoarticular Diseases, Rev.Chim.(Bucharest), 68, no.10, 2017, p.2440-2442

3.CRAUCIUC, D.V.A., CRAUCIUC, E.G., IOV, C.J ., FURNICA, C., IOV, T., Non-invasive Evaluation of Neonatal Cerebral Status in the Newborns of Mothers Addicted to Alcohol and Drugs, Rev.Chim.(Bucharest), 69, no.11, 2018, p.4088-4092

4.HUNEA, I., KNIELING, A., IOV, C. J., RISCANU, L., DAVID, S., CIUHODARU, O., BULGARU ILIESCU, D., Sudden death in epilepsy: case report and literature review, International Journal of Medical Dentistry, vol. 21(4): 253-260

5.UNTU, I., CHIRITA, R., BULGARU-ILIESCU, D., CHIRILA, D.B., CIUBARA, A., BURLEA, S.L., Ethical Implications of Bio-Psycho-Social Transformations Entailed by the Aging Process, Revista de Cercetare si Interventie Sociala, 2015, vol. 48: 216-225

6.RADU, C., BULGARU-ILIESCU, D., RAHOTA, D., PERJU DUMBRAVA, D., Ethical notions in catastrophies, Revista Romana de Bioetica, 2014, vol. 12(2): 53-57

7.CIUBARA, A. B., NECHITA, A., TUDOR, R. C., MATEI, M., TUTUNARU, D., SIRBU, P. D., Social and Medical Ethics: Implications for Romanian Protocols Regarding the Therapy of Alcohol Withdrawal Syndrome in Trauma Patients, Revista de Cercetare si Interventie Sociala, 2018, vol. 60: 174-179

8.FURNICA, C., KNIELING, A., DAMIAN, S. I., DIAC, M., DAVID, S., BULGARU ILIESCU, D., SANDU, I., IOV, C.J., Fatal Ethylene Glycol Intoxication Secondary to Accidental Ingestion, Rev.Chim.(Bucharest), 68, no.7, 2017, p.1591-1594

9. HANNA PRUETER, MATHIAS FRANZ, SUSANNE AULS, GABOR CZIRJ AK, OKSANA GREBEN, ALEX GREENWOOD D, OLGA LISITSYNA, YAROSLAV SYROTA, JILJI SITKO, OLIVER KRONE, Chronic lead intoxication decreases intestinal helminth species richness and infection intensity in mallards (Anas platyrhynchos), Science of the Total Environment, 2018, 644: 151-160

10.WENGER SANDRA, PENDL HELENE, TAHASSTAMATIOS, BOCHMANN MONIKA, HATTJEAN-MICHEL, Clinical signs, diagnosis, and treatment of lead intoxication in an electric eel (Electrophorus Electricus), Journal of Zoo and Wildlife Medicine, 2018. vol. 49, no. 4: 1029-1031 11.PROTSENKO YURI, KATSNELSON BORIS A., KLINOVA SVETLANA V., LOOKIN OLEG N., BALAKIN ALEXANDER A., NIKITINA LARISA V., GERZEN OKSANA P., MINIGALIEVA ILZIRA A., PRIVALOVA LARISA I., GURVICH VLADIMIR B. and others, Effects of subchronic lead intoxication of rats on the myocardium contractility, Food and Chemical Toxicology, 2018, vol. 120: 378-389

12.ADLI DJ ALLAL EDDINE HOUARI, HACHEM KADDA, BENREGUIEG MOKHTAR, BRAHMI MUSTAPHA, KAHLOULA KHALED, MILOUD SLIMANI, The efficiency of Syzygium aromaticum essential oil against renal intoxication by lead in rats during development, Bioscience Research, 2018, vol. 15, no. 3: 2126-2133

13.TOCCHINI DE FIGUEIREDO FELLIPE AUGUSTO, RAMOS JUNIA, HASHIMOTO KAWAKITA ERIKA R., BILAL ALINA S., DE SOUSA FREDERICO B., SWAIM WILLIAM D., MARDEGAN ISSA JOAO P., GERLACH RAQUEL F., Lead line in rodents: an old sign of lead intoxication turned into a new method for environmental surveillance, Environmental Science and Pollution Research, 2016, vol. 23, no. 21: 21475-21484

14.NICULESCU 0, NICA P, GURLUI S, FORNA N, CASIAN-BOTEZ I, IONITA I, CONSTANTIN B, BADARAU GHEORGHE, Experimental Investigations of Polymer Plasma Laser Ablation, Mat. Plast., 46, no. 3, 2019, p. 336-338

15.BELEI, D., FORNA, N.C., SANDU, I., BIRSA, M., Novel Mesoionic 2Methy1-4-(1,3-Dithiol-2-yllum)phenolates, Rev. Chim. (Bucharest), 65, no.1, 2014, p.80-83

16.BAHRIN, L.G., LUNGU, N.C., FORNA, N.C., SANDU, I., BIRSA, M.L., Zwitterionic 3-(1,3-Dithiol-2-ylium)phenolates, Rev.Chim.(Bucharest), 64, no.11, 2013, p.1343-1346

17.BUENZERIC J ., PARRY GARETH J ., Chronic Lead Intoxication From Eating Wild-Harvested Game, American J ournal of Medicine, 2018, vol. 131, no. 5: E181-E184
18.MEHTA VARUN, MIDHA VANDANA, MAHAJAN RAMIT, NARANG VIKRAM, WANDER PRANEET, SOOD RIDHI, SOOD AJIT, Lead intoxication due to ayurvedic medications as a cause of abdominal pain in adults, Clinical Toxicology, 2017, vol. 55, no. 2: 97-101 19.BUDNIK LYGIA THERESE, BAUR XAVER, HARTH VOLKER, HAHN AXEL, Alternative drugs go global: possible lead and/ or mercury intoxication from imported natural health products and a need for scientifically evaluated poisoning monitoring from environmental exposures, Journal of Occupational Medicine and Toxicology, 2016, vol. 11, Article Number: 49

20.MOUGUI AHMED, EL BOUCHTI IMANE, Lead intoxication revealing sickle cell disease, Pan African Medical Journal, 2018, vol. 30, Article Number: 305

21.KAMENSKY OLIVIA, HORTON DESTINY, KINGSLEY DONALD P., BRIDGES CHRISTY C., A case of accidental mercury intoxication, J ournal of Emergency Medicine, 2019, vol. 56(3): 275-278

22.HITOSUGI MASAHITO, TOJO MISA, KANE MASATERU, SHIOMI NAOTO, SHIMIZU TAKESHI, NOMIYAMA TETSUO, Criminal mercury vapor poisoning using heated tobacco product, International J ournal of Legal Medicine, 2019, vol. 133(2): 479-481

23.CHENG YA-YUN, CHANG YU-TZU, CHENG HONG-LIN, SHEN KUNHUNG, SUNG JUNNE-MING, GUO, HOW-Ran, Associations between arsenic in drinking water and occurrence of end-stage renal disease with modifications by comorbidities: A nationwide population-based study in Taiwan, Science of the Total Environment, 2018, vol. 626: 581591

24.SACHELARIE L., FARCAS D. M., DARTU L., VASILIU M., DARABA 0., NAZARIE S., MOCANU C., BURLUI V., Comparative study of diseases of the stomatognathic system and specific parameters of osteoporosis, Osteoporosis International, nanocrystalline mixed 2016, vol. 27(2): 845-848

25.REZLESCU N., REZLESCU E., SACHELARIE L., POPA P. D., DOROFTEI C., Structural and catalytic properties of mesoporous oxides containing magnesium, Catalysis Communications, 2014, vol. 46: 51-56

26.RADU CARMEN CORINA, PODILA CRISTINA, CAMARASAN ANDREEA, BULGARU-ILIESCU DIANA, PERJU-DUMBRAVA DAN, Ethical professional-personal model of making decisions in forensic medicine, Romanian J ournal of Legal Medicine, 2017, vol. 25(3): 314316

27.MANDRAVEL CRISTINA, STANESCU RODICA, CHOIOSA VALENTINA: Metode fizico-chimice aplicate la mãsurarea noxelor în mediul profesional, Ed. Universitatii Bucuresti, 2003

28.NICULESCU TOMA, TODEA ADRIANA, TOMA ION, PAVEL ANCA, RADU NICULESCU: Medicina Muncii, Editura Medmun Bucuresti, 2003 29.PAUNCU ELENA-ANA: Medicina Muncii, Editura Orizonturi Universitare, Timioara, 2004

30.HOSEN SAEED MOHAMMED IMRAN, DAS DIPESH, KOBI RUPKANOWAR, CHOWDHURY DIL UMME SALMA, ALAM MD JIBRAN, RUDRA BASHUDEV, ABU BAKAR MUHAMMAD, ISLAM SAIFUL, RAHMAN ZILLUR, AL-FORKAN MOHAMMAD, Study of arsenic accumulation in rice and evaluation of protective effects of Chorchorus olitorius leaves against arsenic contaminated rice induced toxicities in Wistar albino rats, Bmc Pharmacology \& Toxicology, 2016, vol. 17, Article Number: 46, DOI: 10.1186/s40360-016-0091-8

31.DANI SERGIO ULHOA, Osteoresorptive arsenic intoxication, Bone, 2013, vol. 53(2): 541-545

32.MARCHISET-FERLAY NATHALIE, SAVANOVITCH CHANTAL, SAUVANTROCHAT MARIE-PIERRE, What is the best biomarker to assess arsenic exposure via drinking water?, Environment International, 2012, vol. 39 (1): 150-171

33.PARK KYUNG SUN, KWON JEE HYUN, PARK SANG HYUK, HA WON, LEE JIHO, AN HYUN CHAN, KIM YANGHO, Acute copper sulfate poisoning resulting from dermal absorption, American Journal Of Industrial Medicine, 2018, vol. 61(9): 783-788

34.CHO YONG SOO, MOON JEONG MI, HOON YONG, LEE JEONG DONG HUN, CHUN BYEONG J O, Successful extracorporeal life support in respiratory failure after copper sulphate ingestion, National Medical Journal of India, 2018, vol. 31(2): 83-85 
35.ABBAOUI ABDELLATIF, TAMEGART LAHCEN, EL FARI RADOUANE, GAMRANI HALIMA, Subcommissural organ-Reissner's fiber complex plasticity in two animal models of copper intoxication and modulatory effect of curcumin: Involvement of serotonin, J ournal of Chemical Neuroanatomy, 2019, vol. 97: 80-86

36. MEZYNSKA MAGDALENA, BRZOSKA MALGORZATA M., Environmental exposure to cadmium-a risk for health of the general population in industrialized countries and preventive strategies, Environmental Science and Pollution Research, 2018, vol. 25(4): 32113232

37.KUMAR NARENDRA, KUMARI VANDNA, RAM CHAND, KUMAR BAGEPALLI SATHYANARAYANA BHARATH, VERMA SUNITA, Impact of oral cadmium intoxication on levels of different essential trace elements and oxidative stress measures in mice: a response to dose, Environmental Science and Pollution Research, 2018, vol. 25(6): 54015411 Special Issue: SI

38.***Hazardous Substances Data Bank [database on the Internet]. [Cited My 30, 2012];Available from:http://toxnet.nlm.nih.gov/cgi-bin/ sis/htmlgenHSDB
39.TOCCHINI DE FIGUEIREDO FELLIPE AUGUSTO, RAMOS JUNIA, HASHIMOTO KAWAKITA ERIKA R., BILAL ALINA S., DE SOUSA, FREDERICO B., SWAIM WILLIAM D. ,MARDEGAN ISSA JOAO P., GERLACH RAQUEL F., Lead line in rodents: an old sign of lead intoxication turned into a new method for environmental surveillance, Environmental Science and Pollution Research, 2016, vol. 23(21): 2147521484

40.CARDIANO PAOLA, FOTI CLAUDIA, GIUFFRE OTTAVIA, On the interaction of $\mathrm{N}$-acetylcysteine with $\mathrm{Pb} 2+, \mathrm{Zn} 2+, \mathrm{Cd} 2+$ and $\mathrm{Hg} 2+$, J ournal of Molecular Liquids, 2016, vol. 223: 360-367

41.MOTAWEI SHIMAA M., GOUDA HOSSAM E., Screening of Blood Levels of Mercury, Cadmium, and Copper in Pregnant Women in Dakahlia, Egypt: New Attention to an Old Problem, Biological Trace Element Research, 2016, vol. 171(2): 308-314

42.DVOROZNAKOVA E. DVOROZNAKOVA M., SOLTYS J ., Heavy metal intoxication compromises the host cytokine response in Ascaris suum model infection, Helminthologia, 2016, vol. 53(1): 14-23

Manuscript received:17.10.2018 